\author{
Katarzyna Klimek \\ https://orcid.org/0000-0001-9951-9264 \\ Uniwersytet Ekonomiczny w Krakowie \\ Wydział Zarządzania \\ Katedra Turystyki \\ kklimek@uek.krakow.pl
}

\title{
IMPLEMENTACJA METODY \\ THE ST. GALLEN MODEL FOR DESTINATION MANAGEMENT (SGDM) W POLSKICH KARPATACH: STUDIUM PRZYPADKU SZEŚCIU BIESZCZADZKICH GMIN
}

\begin{abstract}
Abstrakt: Bieszczady są jednym z pasm górskich leżących w polskich Karpatach. Ich walory przyrodnicze i kulturowe przyciągają corocznie do tej destynacji tysiące polskich i zagranicznych turystów. Pomimo wielu objętych ochroną miejsc o szczególnych walorach przyrodniczych (np. Bieszczadzki Park Narodowy, Rezerwat Biosfery UNESCO i obszary Natura 2000) Bieszczady borykają się obecnie z różnymi problemami środowiskowymi i społecznymi, które często wynikają z dynamicznego, ale chaotycznego rozwoju turystyki na ich obszarze. Brak wspólnej wizji długofalowego rozwoju turystyki (na poziomie gminnym i regionalnym) stanowi jedno z głównych wyzwań, przed którym stoją obecnie podmioty publiczne i prywatne wielu gmin bieszczadzkich. W artykule za-prezentowano rezultaty wdrożenia innowacyjnej metody zarządzania destynacjami - The St.Gallen Model for Destination Management (SGDM) - w wybranych bieszczadzkich gminach. Zastosowana metoda umożliwiła lokalnym „aktorom” turystycznym (publicznym i prywatnym) przystąpienie do procesu holistycznego zarządzania miejscami recepcji turystycznej poprzez identyfikację kluczowych segmentów rynku. W pracy przedstawiono pierwszą próbę zastosowania metody SGDM w Polsce.
\end{abstract}

Słowa kluczowe: destynacje górskie, holistyczne zarządzanie turystyką, model SGDM.

\section{WSTĘP}

Obszary górskie stanowią jedne z kluczowych miejsc recepcji turystycznej na świecie i zajmują drugie - po regionach nadmorskich - miejsce pod względem popularności (Nestorosk, 2012). Odsetek turystów odwiedzających co roku miejscowości górskie szacowany jest na 15-20\% globalnego ruchu turystycznego (Debarbieux, Oiry Varacca, Rudaz, Maselli, Kohler, Jurek, 2014).

Globalizacja i związane $\mathrm{z}$ nią tendencje integracji usług i koncentracji kapitału wywierają coraz większą presję na destynacje górskie, których atrakcyjność opiera się w głównej mierze na walorach przyrodniczych. $\mathrm{W}$ związku z tym te destynacje muszą wciąż udoskonalać swoją ofertę turystyczną, aby móc rywalizować $\mathrm{z}$ innymi miejscami recepcji, m.in. poprzez przywództwo kosztowe lub strategie dyferencjacji produktowej (Baggio, Scott, Cooper, 2010; Baker, Cameron, 2008). W odpowiedzi na wyzwania globalnego rynku turystycznego oraz konieczność zachowania i ochrony zasobów, holistyczne zarządzanie destynacjami turystycznymi sta- je się przedmiotem rosnącego zainteresowania wielu europejskich obszarów górskich (Klimek, Doctor, 2018).

Bieszczady są położone na południowo-wschodnim krańcu polskich Karpat i stanowią jedne $\mathrm{z}$ najpiękniejszych, a zarazem wciąż najbardziej dziewiczych pasm górskich Polski wschodniej. Oprócz wielu atrakcji przyrodniczych, m.in.: urozmaiconej topografii, piękna krajobrazu oraz rzadkich gatunków fauny i flory, region ten oferuje turystom również niezwykłe bogactwo kulturowe i historyczne. Według danych Urzędu Statystycznego w 2017 r. w Bieszczady przybyło 464 tys. turystów z Polski i zagranicy, a liczba odwiedzających z roku na rok wciąż rośnie (Turystyka w województwie podkarpackim, 2018).

Jednakże szybki i czasami niekontrolowany rozwój turystyki na tym obszarze powoduje powstawanie wielu problemów środowiskowych i społecznych (Świgost, 2017). Ponadto brak wspólnej wizji interesariuszy publicznych i prywatnych w zakresie rozwoju turystyki na 
poziomie gminnym i regionalnym prowadzi do częstych konfliktów i rozdrobnienia łańcucha usług turystycznych (Czernek, 2012). Dlatego też holistyczne i zrównoważone zarządzanie turystyką na tym obszarze recepcji wydaje się jednym z kluczowych warunków dla jego długotrwałego i zrównoważonego rozwoju.

Głównym celem niniejszego artykułu jest opis implementacji metody The St. Gallen Model for Destination Management (SGDM), którą zastosowano w sześciu bieszczadzkich gminach. W opracowaniu zawarto szczegółowy opis modelu SGDM, który po raz pierwszy został wdrożony $\mathrm{w}$ polskich górach $\mathrm{w}$ listopadzie i grudniu $2018 \mathrm{r}$.

\section{PRZEGLĄD LITERATURY}

Sformułowanie definicji destynacji turystycznej stanowi wciąż wyzwanie dla wielu badaczy zajmujących się tą tematyką, głównie ze względu na brak wspólnej wizji tego, czym jest obszar recepcji turystycznej. Dlatego w literaturze przedmiotu spotykane są różne podejścia i różnorodne definicje wywodzące się z odmiennych punktów widzenia. Miejsca recepcji turystycznej zostały zdefiniowane np. jako geograficznie ograniczone obszary zdominowane przez podaż, w których turyści decydują się na pobyt i po których podróżują (Biegier, Freyer, 2005; Kim, Richardson, 2003; Pearce, 2014). Wielu autorów podkreśla jednak, że destynacja turystyczna to coś więcej, niż tylko miejsce ograniczone $\mathrm{w}$ przestrzeni geograficznej (Bieger, Beritelli, Laeasser, 2009; Haugland, Ness, Grønseth, Aarstad, 2011). Destynacje różnią się od siebie kompleksowością łańcucha bezpośrednich i pośrednich usług turystycznych, np.: zakwaterowania, wyżywienia, transportu publicznego i prywatnego, informacji dla zwiedzających, obiektów rekreacyjnych, a także gamy atrakcji przyrodniczych i kulturalnych, takich jak krajobrazy, zabytki czy unikatowa atmosfera, czym przyciągają turystów do wybranego miejsca recepcji (A practical guide..., 2007; Buhalis, 2000; Crouch, 2011; Leiper, 1990; Richards, 2002).

Bornhorst, Ritchie i Sheehan (2010) podkreślają, że destynacja turystyczna powinna odgrywać dwie podstawowe role. Po pierwsze ma ona zapewnić dobrobyt społeczny i gospodarczy społeczności, która żyje w jej granicach. Po drugie, aby przyciągnąć odwiedzających, musi ona oferować szeroki wachlarz produktów i usług, wychodząc naprzeciw potrzebom współczesnych turystów.

Odniesienie do potrzeb turystycznych prowadzi do kolejnej definicji, którą akceptuje obecnie większość badaczy. Destynacja turystyczna rozumiana jest wtedy jako "zbiór doświadczeń" nabywanych przez podróżnych, dlatego miejsce recepcji postrzega się jako system, w którym przepływy turystów dynamicznie aktywują sieć usług turystycznych (Barnes, Mattsson, Sørensen, 2014; Gunn, 1972; Keller, 2000; Ritchie, Hudson, 2009). Wzdłuż poszczególnych segmentów ruchu turystycznego dostawcy usług turystycznych tworzą swój łańcuch dostaw i czerpią korzyści z wydatków osób podróżujących (Beritelli, 2011a; Pearce, 2014).

Ze względu na presję związaną z globalizacją coraz bardziej rozpowszechniona staje się substytucja dóbr i usług, co szczególnie zdaje się dotykać destynacje opierające się na atrakcjach naturalnych (Dwyer, Edwards, Mistilis, Roman, Scott, 2009). Z tego powodu, w celu uzyskania przewagi konkurencyjnej, każdy obszar docelowy powinien odróżniać się od konkurencji poprzez dynamiczny i innowacyjny łańcuch usług i doświadczeń dostarczanych turystom (Fine, 2000; Gursoy, Saayman, Sotiriadis, 2015; Klimek, Doctor, 2018; Vengesayi, 2003). Należy jednak pamiętać, że - jak twierdzą Padurean (2010), Laesser i Beritelli (2013) oraz inni autorzy cytowani w literaturze - zarządzanie destynacjami górskimi wiąże się obecnie $\mathrm{z}$ wieloma wyzwaniami. Ponieważ w tych miejscach recepcji łańcuch usług turystycznych tworzą zazwyczaj różni usługodawcy (lokalni i zewnętrzni), jest on często fragmentaryczny i podzielony między heterogeniczne grupy interesariuszy (Beritelli, 2011b). W związku z tym tradycyjny, odgórny model zarządzania (top-bottom), powszechnie stosowany $\mathrm{w}$ destynacjach górskich, zazwyczaj nie jest spójny z różnorodnymi i często sprzecznymi interesami tych grup (Beriteli, Laesser, 2011; Byrd, 2007; Lai, Hsu, Wearing, 2016; Sheehan, Ritchie, 2005; Pechlaner, Tschurtschenthaler, 2003). $Z$ tego powodu już od lat 60. XX w. zarządzanie turystyką w szwajcarskich i innych destynacjach alpejskich ewoluowało od klasycznego podejścia opartego głównie na działaniach marketingowych i promocyjnych, do podejścia oddolnego (bottom-up), bazującego na szeroko pojętej współpracy oraz mniej zbiurokratyzowanych i zdecentralizowanych formach zarządzania miejscami docelowymi. Przejawem tej wspó1pracy było utworzenie na obszarach turystycznych Destination Management Organizations (DMOs) (Bieger, 1998; Beritelli, Bieger, Laesser, 2007).

Destination Management Organizations (DMOs) są organizacjami bazującymi na partnerstwie publiczno-prywatnym. Ich funkcjonowanie oparte jest bowiem na koalicji wielu interesariuszy turystycznych (publicznych i prywatnych), którzy działają wspólnie na rzecz osiągania założonych celów strategicznych (A practical guide..., 2007; Elbe, Hallén, Axelsson, 2009). DMOs są najczęściej podmiotami o charakterze niezarobkowym. Ich główne działania skupiają się m.in. na: strategicznym zarządzaniu miejscami recepcji, kształtowaniu spójnej strategii marketingowej i wizerunkowej, informacji i animacji turystycznej, współpracy z lokalnymi grupami interesów w celu komercjalizacji produktów turystycznych oraz lobbingu i ochrony interesów mieszkańców (Gertzel, Fesenmaier, Formica, O'Leary, 2006; Presenza, Sheehan, Ritchie, 2005). 
Szwajcaria jest jednym z pierwszych krajów, w których tego rodzaju organizacje utworzono na szczeblu lokalnym i regionalnym $\mathrm{w}$ ramach partnerstwa publiczno-prywatnego (Klimek, 2014). DMOs funkcjonują także $\mathrm{z}$ powodzeniem $\mathrm{w}$ wielu innych europejskich i pozaeuropejskich destynacjach turystycznych, jednakże w licznych górskich regionach i miejscowościach turystycznych postrzeganie holistycznego zarządzania miejscami docelowymi spotyka się nadal z dużym oporem wśród różnorodnych grup interesariuszy (Baggio, Scott, Cooper, 2010; Benčič, 2006). Polska jest krajem, w którym stosunkowo słabo funkcjonują rozwiązania wdrażane $\mathrm{w}$ zakresie holistycznego zarządzania turystyką na podstawie partnerstwa publiczno-prywatnego. Jest to widoczne na wszystkich poziomach zarządzania turystyką - lokalnym, regionalnym i ogólnokrajowym (Fedyk, Meyer, Potocki, 2017).

Pomimo coraz powszechniejszego przekonania, że lokalne i regionalne organizacje turystyczne działające w naszym kraju powinny nie tylko promować miejsca recepcji turystycznej, ale także kompleksowo zarządzać przepływami turystów, nadal nie mają one wystarczających kompetencji i kwalifikacji w tym zakresie (Borzyszkowski, 2013; Czernek, 2012; Klimek, 2013). Problem ten istnieje również w regionie Bieszczad. Według Szulc-Dąbrowieckiej i Żuławskiej (2015) można wyróżnić dwa główne etapy zarządzania turystyką na tym terenie. Etap pierwszy to okres zarządzania centralnego, przypadający na lata 1952-1989, kiedy organy państwa i władzy lokalnej odgrywały dominującą rolę w zarządzaniu turystyką. Etap drugi rozpoczął się po 1990 r. i trwa do chwili obecnej. Charakteryzuje się on zdecentralizowanym zarządzaniem turystyką w miejscach recepcji, której rozwijaniem na szczeblach regionalnym i lokalnym zajmują się różne podmioty oraz organizacje publiczne i prywatne. Ich role i kompetencje często się na siebie nakładają, co ma wpływ na kierunki i skuteczność podejmowanych działań. $Z$ tego względu, pomimo wielu dokumentów strategicznych, opracowanych w ostatnich latach dla harmonijnego rozwoju tego regionu, nadal brakuje tu holistycznego podejścia do zarządzania ruchem turystycznym. Tymczasem, masy turystów napływające co roku do najbardziej atrakcyjnych obszarów tego regionu, np.: w rejon Jeziora Solińskiego lub do Bieszczadzkiego Parku Narodowego, powodują liczne problemy społeczne i środowiskowe (Myga-Piątek, Jankowski, 2009; Świgost, 2017; Wolski, 2007).

Jednocześnie najliczniejsze skupiska turystów przybywających na teren Bieszczad koncentrują się głównie na obszarach oferujących najważniejsze atrakcje, pomijając przy tym wiele interesujących przyrodniczo i kulturowo obiektów znajdujących się w sąsiednich gminach (np. w gminie Lesko, Baligród czy Ustrzyki Dolne). Ponadto ruch turystyczny w regionie Bieszczad odznacza się wyraźną sezonowością i nasila się przede wszystkim w okresie letnim, tj. od maja do początku listopada (Turystyka w województwie podkarpackim..., 2018). $Z$ tego powodu opisywany region potrzebuje przykładów dobrych praktyk z innych destynacji górskich, które już wprowadziły nowe standardy oparte na holistycznej koncepcji zarządzania destynacjami. Stąd pomysł implementacji nowatorskiej metody zarządzania, tj. SGDM, w wybranych gminach bieszczadzkich.

Model SGDM oferuje zorientowaną na popyt realistyczną perspektywę długofalowego rozwoju miejsc recepcji, która oparta jest na następujących założeniach (Beritelli, Reinhold, Laesser, Bieger, 2015):

1. Destynacja turystyczna jest przestrzenią kreowaną i definiowaną przez turystę.

2. Większość turystów przyjeżdżających do miejsca recepcji poszukuje zaspokojenia podobnych potrzeb, w związku z tym zachowuje się podobnie i aktywuje zbliżone elementy łańcucha usług. Zatem to popyt turystyczny decyduje o podaży, a nie odwrotnie.

3. Strategiczne przepływy turystów (Strategic Visitor Flows -SVFs) są podstawowymi jednostkami planowania strategicznego i holistycznego zarządzania miejscami docelowymi.

4. Odtworzenie drogi, jaką przybywają i poruszają się $w$ destynacji strategiczne segmenty (SVFs), pozwala na zoptymalizowanie natężenia ruchu turystycznego i na adekwatne dopasowanie oferty miejsc recepcji do realnych potrzeb turystów.

5. Stosując model SGDM, nie odwołujemy się do ilościowych analiz ruchu turystycznego, które są często fragmentaryczne i nieporównywalne ze sobą, ale opieramy się na wiedzy i doświadczeniu kluczowych interesariuszy publicznych i prywatnych zaangażowanych w rozwój turystyki w danej destynacji. Są to np.: przedsiębiorcy turystyczni, stowarzyszenia i organizacje turystyczne oraz NGOs i nieformalne grupy interesów, ale także podmioty publiczne, czyli władze lokalne i regionalne. Podmioty te odgrywają kluczową rolę w identyfikacji SVFs i od ich zaangażowania i chęci współpracy zależy skuteczność implementacji metody.

6. Planowanie działań strategicznych i podział zadań są w tym modelu realizowane dla każdego kluczowego segmentu oddzielnie, a nie kompleksowo dla całej destynacji. Pozwala to na optymalizację wydatków przeznaczanych na marketing i promocję oraz lepsze zarządzanie zasobami, dzięki efektywniejszemu planowaniu działań podczas całego procesu.

Ten prorynkowy i oparty na współpracy model stworzony został na podstawie praktycznych doświadczeń w pracy z destynacjami turystycznymi szwajcarskich naukowców z Uniwersytetu St. Gallen. Od momentu powstania (tj. od $2010 \mathrm{r}$.) został przetestowany w ponad 40 miejscowościach turystycznych w Europie i na świecie. W listopadzie i grudniu 2018 r. po raz pierwszy zastosowano model SGDM w Polsce1. Badaniem objęto sześć bieszczadzkich gmin: Baligród, Cisna, Lesko, Olszanica, 
Solina i Ustrzyki Dolne ${ }^{2}$. Przed zastosowaniem metody dokonano wstępnej diagnozy rozwoju turystyki w poszczególnych gminach w celu poznania ich mocnych i słabych stron $w$ zakresie rozwoju turystyki.

\section{METODYKA I PYTANIA BADAWCZE}

Model SGDM, który został zaimplementowany w wybranych gminach Bieszczad, składa się z sześciu kroków i koncentruje się na następujących działaniach:

- identyfikacji strategicznych przepływów odwiedzających (SVFs) i ich graficznej wizualizacji na mapach przygotowanych dla poszczególnych destynacji;

- stworzeniu portfolio strategicznych segmentów (SVFs) dla każdej z wybranych gmin poprzez analizę danych zawartych na mapach, scalanie podobnych wyników i pomijanie powtórzeń;

- analizie i rekonstrukcji powiązań między popytem i podażą w odniesieniu do zidentyfikowanych strategicznych przepływów odwiedzających (SVFs);

- ocenie istniejących działań marketingowych dla każdego kluczowego segmentu i planowaniu nowych działań strategicznych dla istniejących i nowych SVFs;

- dokonywaniu bieżącej aktualizacji działań marketingowych i zarządczych $w$ odniesieniu do istniejących i potencjalnych SVFs, poprzez wspólny proces decyzyjny podejmowany przez uczestniczących w projekcie najważniejszych interesariuszy na podstawie zrównoważonego wykorzystania zasobów.
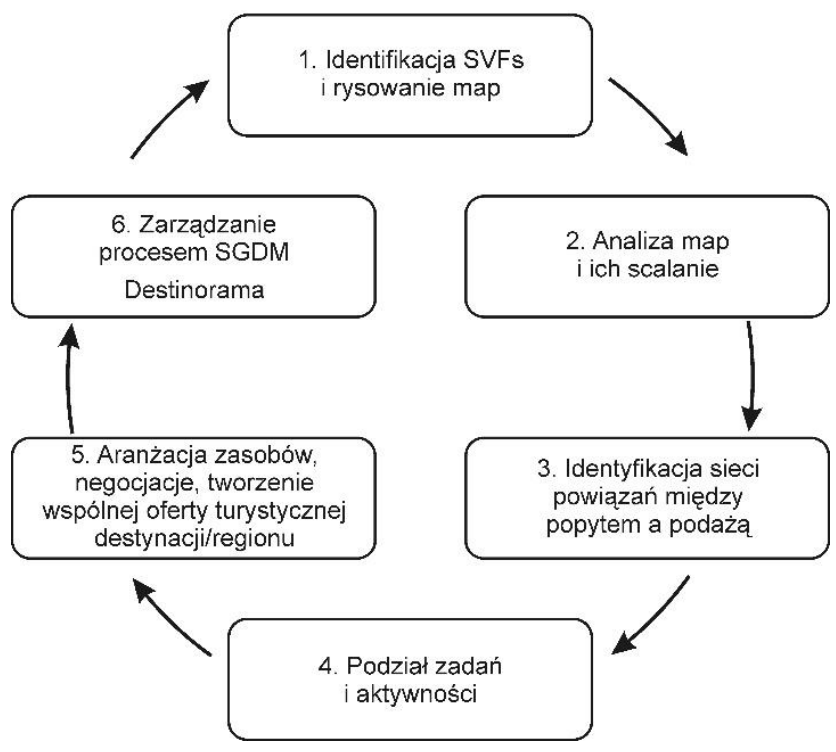

Rysunek 1. Istota modelu SGDM zastosowanego w wybranych gminach Bieszczad

Źródło: opracowanie autorki na podstawie: Beritelli, Reinhold, Laesser, Bieger (2015)
W metodzie tej zakłada się, że przechodzenie z jednego etapu do kolejnych kroków jest procesem, w który zaangażowani są strategiczni lokalni interesariusze. Dzięki identyfikacji SVFs oraz wspólnemu planowaniu działań w sposób kompleksowy zarządzają oni kluczowymi przepływami turystów (rys. 1).

Identyfikacji SVFs dla każdej gminy objętej badaniem i oceny dotychczasowych wyzwań związanych z zarządzaniem przepływami turystów dokonano podczas spotkań roboczych zorganizowanych z kluczowymi lokalnymi interesariuszami.

Biorąc pod uwagę wszystkie aspekty modelu SGDM oraz opierając się na kwestiach teoretycznych poruszonych w literaturze, jako cel implementacji modelu w wybranych gminach obrano znalezienie odpowiedzi na następujące pytania badawcze:

1. Jakie strategiczne przepływy odwiedzających (SVF) można zidentyfikować $\mathrm{w}$ wybranych bieszczadzkich gminach i jak te segmenty są rozwinięte (pod względem liczby odwiedzających oraz ich cyklu życia)? Jakie rodzaje SVFs mogą być rozwijane w przyszłości?

2. Jakie są obecnie relacje popytu do podaży usług turystycznych i jacy kluczowi interesariusze angażują się w rozwój turystyki na wybranym obszarze badawczym?

3. Jakie główne problemy $\mathrm{w}$ zarządzaniu istniejącymi SVFs można zidentyfikować $i$ jakie są możliwe rozwiązania, m.in. w zakresie kreowania nowych produktów turystycznych i pobudzania współpracy wewnątrzgminnej oraz między gminami?

4. Czy koncepcja SGDM jest skutecznym narzędziem pobudzania współpracy wewnątrzgminnej i między gminami dla długofalowego rozwoju turystyki w sześciu analizowanych jednostkach?

\section{OPIS PRÓBY BADAWCZEJ ORAZ PROCESU WDROŻENIA MODELU SGDM}

Wdrożenie metody wymagało kilkumiesięcznych przygotowań związanych przede wszystkim z doborem kluczowych interesariuszy oraz przygotowaniem materiałów (map) stanowiących podstawowy element spotkań roboczych. Dobór próby badawczej (podmiotów publicznych i prywatnych) został dokonany na podstawie ściśle określonych kryteriów, czyli:

- wybrano podmioty, które obecnie odgrywają kluczową rolę $\mathrm{w}$ rozwoju ruchu turystycznego $\mathrm{w}$ poszczególnych gminach oraz $\mathrm{w}$ kreowaniu produktu turystycznego gmin;

- stwierdzono, że istnieje między nimi sieć powiązań, choć obecnie w różnym stopniu i zakresie ze sobą współpracują; należy jednak pamiętać, że turystyka jest dla nich ważnym sektorem gospodarki i źródłem przychodów ${ }^{3}$. 
W ramach procesu selekcji wybrano pięć kluczowych grup interesariuszy, tj.:

1) lokalnych gestorów bazy turystycznej, czyli przedstawicieli sektora zakwaterowania, gastronomii i atrakcji turystycznych;

2) lokalnych organizatorów turystyki, takich jak: biura podróży, górscy przewodnicy turystyczni;

3) reprezentantów Lasów Państwowych;

4) przedstawicieli władz lokalnych (gmin i powiatów);

5) lokalne grupy działania / stowarzyszenia / przedstawiciele innych organizacji pozarządowych.

Spotkania $\mathrm{z}$ interesariuszami podzielonymi branżowo odbyły się w miejscowościach Orelec i Ustrzyki Dolne w listopadzie i grudniu 2018 r. Wzięło w nich udział około 50 przedstawicieli branżowych z sześciu gmin ${ }^{4}$.

$\mathrm{Na}$ początku wszystkich spotkań przedstawiono uczestnikom cechy charakteryzujące każdy kluczowy segment turystów (SVFs) w celu odróżnienia strategicznych segmentów turystów od innych grup odwiedzających. Tak oto każdy SVFs:

- jest złożony z dużej liczby turystów i powtarzalny,

- jest relatywnie stabilny i przewidywalny w czasie,

- może być zlokalizowany na 2-3 rodzajach map,

- posiada własny mechanizm podaży i popytu,

- może być stymulowany przez podaż,
- ma własną dynamikę i cykl życia oraz generuje możliwość zarobku,

- może być analizowany, zarządzany i komercjalizowany.

Następnie interesariusze zaznaczyli zidentyfikowane segmenty na uprzednio przygotowanych mapach. W zależności od wielkości gminy wydrukowano je dla każdej z gmin w dwóch lub trzech skalach (zob. rys. 2). Rozpoczynając pracę $\mathrm{z}$ mapami, przedstawiciele gmin najpierw narysowali drogę, jaką pokonują turyści z SVFs, przyjeżdżając do danej gminy, oraz zaznaczali wszystkie atrakcje i elementy podaży, które aktywują strategiczne przepływy turystów podczas pobytu w wybranym miejscu recepcji. Każdy SVFs zaznaczano i opisywano oddzielnie na jednym rodzaju mapy. Poza graficznym umiejscowieniem na mapach wszystkich kluczowych segmentów turystów ważnym elementem procesu było również dokładne opisanie każdego SVFs, poprzez wypełnienie legendy zamieszczonej pod każdą mapą.

Legenda składa się z kilku pól, które pozwalają szczegółowo opisać każdy ważny segment turystów. Interesariusze charakteryzowali każdy kluczowy przepływ poprzez udzielnie odpowiedzi na następujące pytania:

- Kim są najważniejsi goście? Jaką nazwę można nadać temu segmentowi (SVFs)?

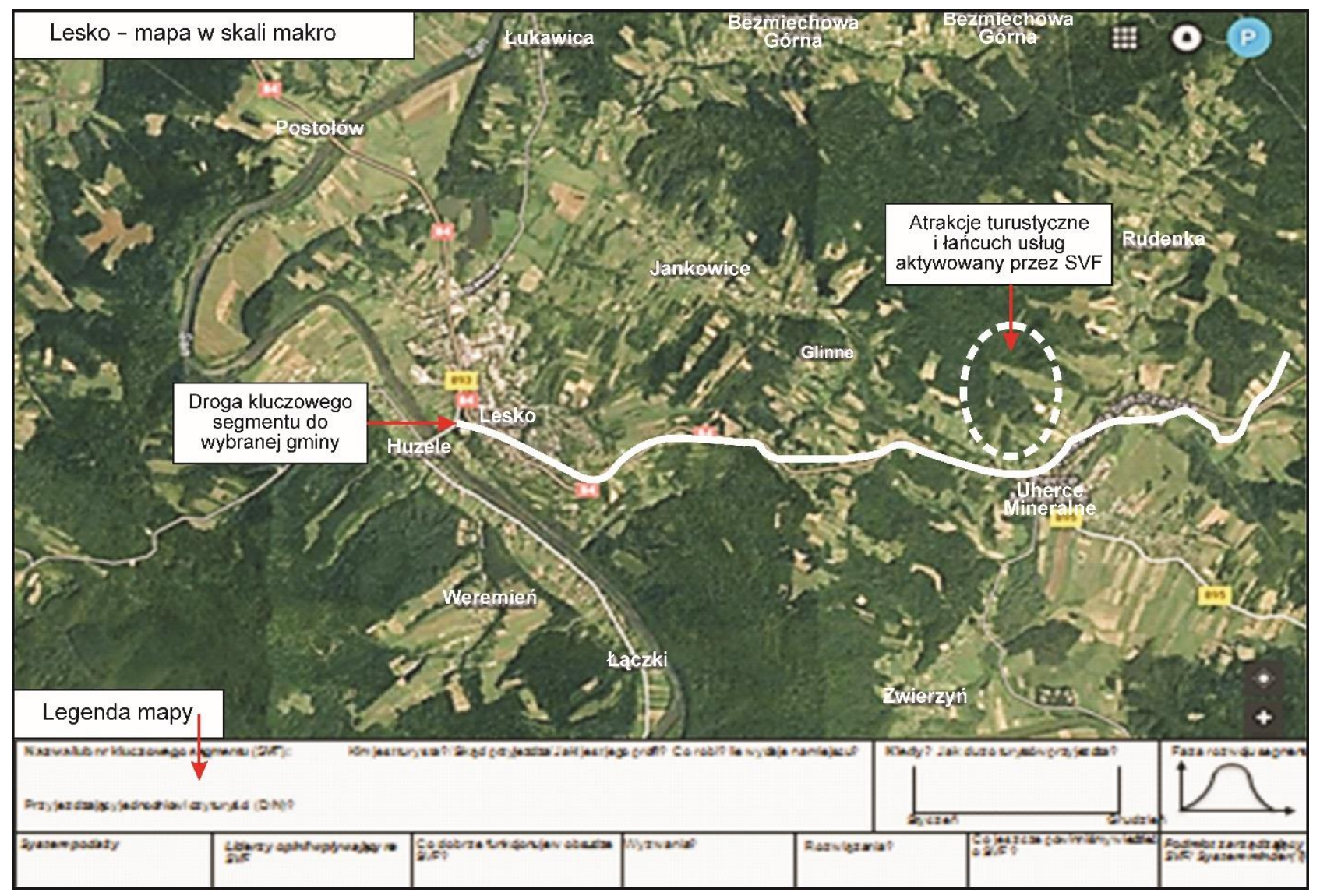

Rysunek 2. Przykład mapy Leska i okolic w skali makro

Źródło: opracowanie własne na podstawie Beritelli, Reinhold, Laesser, Bieger (2015) 
- Czy są to odwiedzający jednodniowi czy turyści?

- Skąd pochodzą odwiedzający? Dokąd idą i co robią podczas pobytu? Co kupują i ile pieniędzy wydają?

- Dlaczego turyści przyjeżdżają do naszej gminy?

- Kiedy przyjeżdżają?

- Jaka jest faza cyklu życia kluczowego segmentu (SVFs)?

Dolna część legendy służyła do określenia, jakie kluczowe elementy podaży - system head(s) - oraz jacy liderzy opinii - market mavens - wpływają na każdy analizowany kluczowy segment.

Zastosowana metoda pozwoliła także określić, co dobrze funkcjonowało w obsłudze opisywanego segmentu, a co wciąż pozostaje do poprawienia. Możliwe rozwiązania stanowiły kanwę do dyskusji między interesariuszami, w celu zaplanowania konkretnych działań, aby dopasować podaż do potrzeb zidentyfikowanych SVFs.

\section{PREZENTACJA WYNIKÓW}

Efektem przeprowadzonych spotkań było wypełnienie 52 map oraz zidentyfikowanie 32 istniejących SVFs w sześciu bieszczadzkich gminach oraz trzy segmenty potencjalne, których rozwój planowany jest w przyszłości (tab. 1). Po scaleniu map i wyeliminowaniu powtórzeń wyniki pracy z pierwszych spotkań zostały zaprezentowane interesariuszom $\mathrm{w}$ postaci tzw. destinoramy (ekspozycji utworzonej ze wszystkich, wydrukowanych map) na podsumowującym spotkaniu roboczym, które odbyło się w grudniu 2018 r. w miejscowości Ustrzyki Dolne.

Tabela 1. Zestawienie wypełnionych map oraz zidentyfikowanych kluczowych SVFs w 2018 r.

\begin{tabular}{|l|c|c|}
\hline Nazwa gminy & $\begin{array}{c}\text { Liczba } \\
\text { wypełnionych } \\
\text { map }\end{array}$ & $\begin{array}{c}\text { Liczba } \\
\text { zidentyfikowanych klu- } \\
\text { czowych segmentów }\end{array}$ \\
\hline Baligród & 6 & $4+3$ potencjalne \\
\hline Cisna & 10 & 7 \\
\hline Olszanica & 5 & 2 \\
\hline Lesko & 18 & 7 \\
\hline Solina & 6 & 7 \\
\hline Ustrzyki Dolne & 7 & $4+1$ potencjalny \\
\hline Łącznie & 52 & 34 \\
\hline
\end{tabular}

Źródło: opracowane własne na podstawie przeprowadzonych spotkań.

W tab. 2. (zob. s. 63-64) przedstawiono charakterystykę najważniejszych SVFs w sześciu bieszczadzkich gminach.

Podczas pracy nad mapami - w wyniku rozmów i dyskusji toczących się na spotkaniach roboczych - zidentyfikowano także najważniejsze problemy i wyzwania w zakresie zarządzania SVFs. Przyczyniło się to do opracowania propozycji rozwiązań, które angażują zarówno interesariuszy publicznych, jak i prywatnych. Główne problemy oraz propozycje tych rozwiązań zestawiono w tab. 3 (zob. s. 64-66).

Zastosowany model SGDM i wyniki kwestionariusza ankietowego ${ }^{5}$ rozdanego uczestnikom po spotkaniu pozwoliły również lepiej zrozumieć obecną sytuację dotyczącą poziomu współpracy głównych interesariuszy publicznych i prywatnych oraz określić ich rolę w zarządzaniu strategicznymi segmentami (zob. rys. 3).

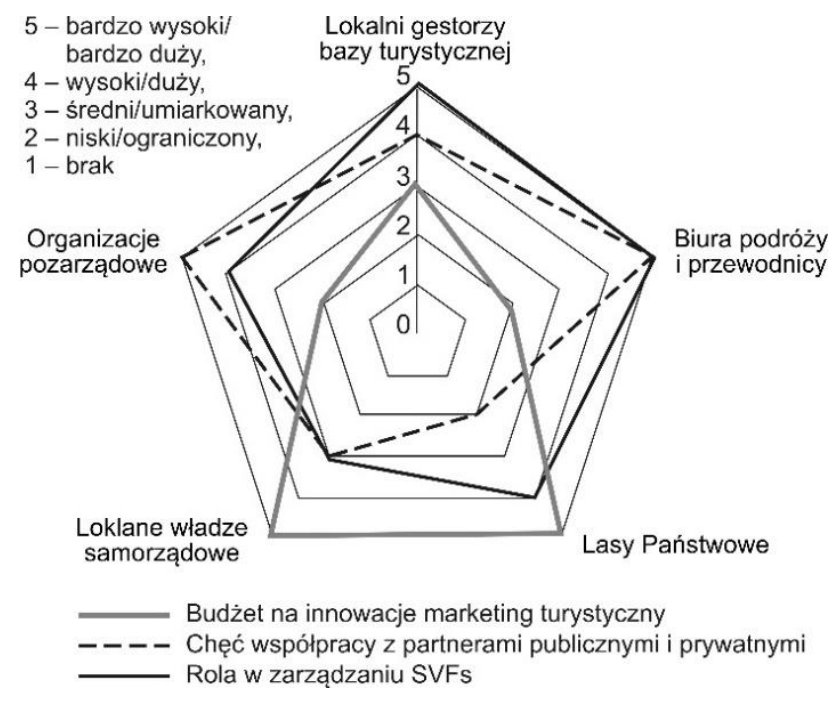

Rysunek 3. Poziom współpracy i rola poszczególnych grup interesariuszy w zarządzaniu SVFs Źródło: opracowanie własne na podstawie podejścia SGDM i wyników badania

Jednym z najważniejszych rezultatów wdrożenia opisywanej w niniejszym artykule metody było dostrzeżenie przez lokalnych interesariuszy tego, w jakich miejscach łańcucha dostaw brakuje efektywnej współpracy. Analiza podaży pozwoliła także na uzyskanie podstawowej charakterystyki kluczowych podmiotów, ich roli w obsłudze SVFs oraz woli wzajemnej współpracy na obszarze sześciu gmin w zakresie rozwoju turystyki. Charakterystyka tych podmiotów jest następująca:

- Lokalni gestorzy bazy i atrakcji turystycznych mają największą wolę współpracy w celu pobudzenia turystyki w wybranych gminach. Ich obecna działalność i otwartość na innowacje są kluczowe dla przyciągnięcia nowych segmentów turystów do tego regionu. Są to jednak głównie mali przedsiębiorcy z ograniczonymi źródłami. finansowania.

- W przeciwieństwie do przewodników turystycznych lokalne biura podróży są bardzo otwarte na szeroką współprace publiczno-prywatną. Obie te grupy podmiotów odgrywają znaczącą rolę w turystyce przyjazdowej.

- Ponieważ obszary leśne stanowią ponad 60\% całego terytorium Bieszczad, Lasy Państwowe są bardzo ważnym publicznym interesariuszem, mającym 
wpływ na rozwój turystyki również na terenie sześciu analizowanych gmin. Podmiot ten podejmuje działania dotyczące stymulowania turystyki raczej samodzielnie. Jako że dysponuje on dużymi środka$\mathrm{mi}$ finansowymi, aktywnie angażuje się $\mathrm{w}$ tworzenie nowych atrakcji turystycznych i obiektów noclegowych. Utrzymuje również szlaki turystyczne i inną infrastrukturę na terenie badanych gmin. W przypadku kluczowych inwestycji Lasy Państwowe częściej nawiązują współpracę z samorządami lokalnymi niż z partnerami prywatnymi.

- Ze względu na posiadane środki finansowe samorządy lokalne odgrywają bardzo istotną rolę w kreowaniu kierunków rozwoju turystyki na obszarze sześciu gmin bieszczadzkich, jednak często mają one inną wizję jej rozwoju niż podmioty prywatne. Ponadto analizowane destynacje to często małe gminy, które nie dysponują wystarczającymi zasobami ludzkimi, aby kompleksowo zarządzać lokalną turystyką.

- Organizacje pozarządowe działają blisko społeczności lokalnych, uczestnicząc bardzo aktywnie $\mathrm{w}$ inicjowaniu różnego rodzaju projektów, tworzeniu produktów turystycznych i atrakcji (np. Eko-muzeum).
Jednak często borykają się one z problemami kadrowymi i finansowymi.

Podczas spotkań wymienieni interesariusze uznali konieczność wspólnych prorynkowych działań, aby z jednej strony zintensyfikować napływ turystów z kluh segmentów (SVFs), a z drugiej - promować atrakcje przyrodnicze i kulturowe, które pomimo dużej wartości poznawczej są często pomijane przez przyjeżdżających turystów. Wydaje się to mieć szczególne znaczenie w kontekście dynamicznego napływu turystów do gminy Solina. Ze względu na zróżnicowaną ofertę turystyczną to miejsce recepcji przyciąga masowego turystę, zwłaszcza w okresie od maja do listopada, natomiast pacjenci uzdrowiskowi przyjeżdżają do Polańczyka na leczenie sanatoryjne przez cały rok. Znaczna koncentracja ruchu turystycznego, szczególnie na obszarze tej gminy, powoduje duże trudności komunikacyjne w sezonie na trasach dojazdowych zarówno dla turystów, jak i społeczności lokalnej. W związku z tym kreowanie i promocja istniejących i nowych atrakcji w gminach sąsiadujących wydaje się mieć kluczowe znaczenie dla rozładowania natłoku turystów i lepszego zarządzania SVFs na całym analizowanym obszarze.

Tabela 2. Charakterystyka kluczowych segmentów w sześciu badanych bieszczadzkich gminach w 2018 r.

\begin{tabular}{|c|c|c|c|c|c|}
\hline \multirow{2}{*}{$\begin{array}{c}\text { Rodzaj } \\
\text { segmentu }\end{array}$} & \multirow{2}{*}{ Nazwa SVF } & \multirow{2}{*}{ Gmina } & \multirow{2}{*}{ Charakterystyka kluczowego segmentu } & \multicolumn{2}{|c|}{ Przyjeżdżający } \\
\hline & & & & na 1 dzień & turyści \\
\hline \multirow[t]{8}{*}{$\begin{array}{l}\text { Segmenty } \\
\text { istniejące }\end{array}$} & Przyrodnicy & Baligród, Cisna & $\begin{array}{l}\text { Przyrodnicy, pasjonaci, rodziny z dziećmi } \\
\text { z całej Polski, ludzie młodzi, aktywni } \\
\text { fizycznie. }\end{array}$ & & $\mathrm{x}$ \\
\hline & Rodziny z dziećmi & $\begin{array}{l}\text { Baligród, Cisna, } \\
\text { Lesko, Solina, }\end{array}$ & $\begin{array}{l}\text { Rodziny z dziećmi w różnym wieku, podró- } \\
\text { żuące samochodem (z całej Polski). W gminie } \\
\text { Baligród, Cisna i Lesko są to w głównej mierze } \\
\text { turyści tranzytowi, a w gminach Cisna, } \\
\text { Solina turyści nocujący w pensjonatach } \\
\text { od } 3 \text { dni do tygodnia. }\end{array}$ & $\mathrm{x}$ & $x$ \\
\hline & $\begin{array}{l}\text { Grupy znajomych } \\
\text { i studenci }\end{array}$ & Baligród, Cisna & $\begin{array}{l}\text { Studenci szkół wyższych (Kraków, Lublin, Rze- } \\
\text { szów), pary i rodziny wielopokoleniowe. }\end{array}$ & $x$ & $x$ \\
\hline & Grupy szkolne & $\begin{array}{l}\text { Solina, Cisna, } \\
\text { Ustrzyki Dolne }\end{array}$ & $\begin{array}{l}\text { Uczniowie przyjeżdżający na zielone szkoły } \\
\text { lub inne pobyty zorganizowane. Przebywają } \\
\text { nad Soliną kilka dni w okresie wiosenno- } \\
\text {-letnim. }\end{array}$ & $\mathrm{x}$ & \\
\hline & $\begin{array}{l}\text { Turyści tranzytowi } \\
\text { i objazdowi }\end{array}$ & $\begin{array}{l}\text { Baligród, Cisna, } \\
\text { Lesko }\end{array}$ & $\begin{array}{l}\text { Turyści zmotoryzowani z Polski i zagranicy. } \\
\text { Wycieczki zorganizowane, seniorzy, juniorzy } \\
\text { (grupy szkolne zwiedzające zabytki w drodze } \\
\text { nad Solinę). }\end{array}$ & $\mathrm{x}$ & \\
\hline & $\begin{array}{l}\text { DINKS - Double Income } \\
\text { no Kids }\end{array}$ & Cisna & $\begin{array}{l}\text { Bezdzietne pary (starsze małżeństwa), } 80 \% \\
\text { z Warszawy, } 20 \% \text { z Dolnego Śląska i Pomorza. } \\
\text { Pobyty od } 3 \text { do } 7 \text { dni. }\end{array}$ & $x$ & \\
\hline & Samotni wędrowcy & Cisna, Lesko & $\begin{array}{l}\text { Turyści indywidualni, głównie mężczyźni pra- } \\
\text { cujący, z całej Polski, w wieku od } 40 \text { lat. Są to } \\
\text { głównie turyści weekendowi (Cisna) lub jedno- } \\
\text { dniowi (Lesko). }\end{array}$ & $x$ & $x$ \\
\hline & $\begin{array}{l}\text { Uczestnicy wyjazdów in- } \\
\text { tegracyjnych i wycieczki } \\
\text { zakładowe }\end{array}$ & Cisna, Solina & $\begin{array}{l}\text { Pracownicy firm (w wieku 30-60 lat) } \\
\text { z Małopolski (Kraków), woj. mazowieckiego } \\
\text { (Warszawa) i lubelskiego. Najczęściej pobyty } \\
\text { 3-dniowe. }\end{array}$ & & $x$ \\
\hline
\end{tabular}


Tabela 2 (cd.)

\begin{tabular}{|c|c|c|c|c|c|}
\hline \multirow{2}{*}{$\begin{array}{c}\text { Rodzaj seg- } \\
\text { mentu }\end{array}$} & \multirow[b]{2}{*}{ Nazwa SVF } & \multirow[b]{2}{*}{ Gmina } & \multirow[b]{2}{*}{ Charakterystyka kluczowego segmentu } & \multicolumn{2}{|c|}{ Przyjeżdżający } \\
\hline & & & & $\begin{array}{c}\text { na } 1 \\
\text { dzień }\end{array}$ & turyści \\
\hline & $\begin{array}{l}\text { Uczestnicy wydarzenia } \\
\text { „Bieg rzeźnika” }\end{array}$ & Cisna & $\begin{array}{l}\text { Sportowcy z rodzinami z całej Polski } \\
\text { i z zagranicy. Nocują w bazie gminy Cisna, } \\
\text { od } 2 \text { do } 7 \text { dni przed, w trakcie i po wydarzeniu. }\end{array}$ & & $x$ \\
\hline & $\begin{array}{l}\text { „Eduturyści” i turyści } \\
\text { kulturowi }\end{array}$ & $\begin{array}{l}\text { Olszanica, } \\
\text { Ustrzyki Dolne }\end{array}$ & $\begin{array}{l}\text { Turyści indywidualni, grupy zorganizowane } \\
\text { krajowe i zagraniczne, rodziny z dziećmi } \\
\text { i wielopokoleniowe, grupy młodzieży, } \\
\text { motocykliści, rowerzyści, grupy przyjaciół. } \\
\text { Jednodniowi i pobytowi. Zwiedzają: drezyny } \\
\text { rowerowe, Bieszczadzką Szkołę Rzemiosła } \\
\text { i browar Ursa Maior, Ekomuzem, pałac } \\
\text { w Olszanicy, Muzeum Wsi i Rolnictwa. }\end{array}$ & $x$ & $x$ \\
\hline & Narciarze & Lesko & Lokalni narciarze, rodziny z dziećmi. & $x$ & \\
\hline & $\begin{array}{l}\text { Międzynarodowe grupy } \\
\text { wędkarskie }\end{array}$ & Lesko & $\begin{array}{l}\text { Wędkarze (krajowi i zagraniczni), z całej Eu- } \\
\text { ropy, ale głównie Włosi, Francuzi i Czesi. Jest } \\
\text { to segment zamożnych turystów. Przebywają } \\
\text { w Lesku min. } 3 \text { dni, wydając od } 200 \text { do } 500 \text { zł } \\
\text { dziennie na osobę. }\end{array}$ & & $\mathrm{x}$ \\
\hline & $\begin{array}{l}\text { "Wodnicy" - spływy } \\
\text { rzeczne }\end{array}$ & Lesko & $\begin{array}{l}\text { Grupy szkolne oraz grupy osób dorosłych } \\
\text { z całej Polski. }\end{array}$ & $x$ & \\
\hline & Żeglarze & Solina & $\begin{array}{l}\text { Żeglarze lokalni i z całej Polski, młodzież, stu- } \\
\text { denci, rodzice z dziećmi. Pobyty żeglarskie kil- } \\
\text { kudniowe w okresie letnim. }\end{array}$ & & $\mathrm{x}$ \\
\hline & $\begin{array}{l}\text { Szybownicy } \\
\text { i paralotniarze }\end{array}$ & Lesko & $\begin{array}{l}\text { Turyści aktywni, sportowcy, turyści chcący } \\
\text { skorzystać z lotów widokowych. Jednodniowi } \\
\text { oraz goście pozostający kilka dni na szkole- } \\
\text { niach. }\end{array}$ & $\mathrm{x}$ & $\mathrm{x}$ \\
\hline & $\begin{array}{l}\text { Biegacze i „swimrunne- } \\
\text { rzy” }\end{array}$ & Solina & $\begin{array}{l}\text { Sportowcy z Polski i Europy. Turyści spędza- } \\
\text { jący około tygodnia nad Jeziorem Solińskim w } \\
\text { celu treningów sportowych. }\end{array}$ & & $\mathrm{x}$ \\
\hline & Kuracjusze & Solina & $\begin{array}{l}\text { Kuracjusze przyjeżdżający przez cały rok na } \\
\text { leczenie sanatoryjne do Polańczyka z woj.: ma- } \\
\text { łopolskiego, śląskiego, lubelskiego i mazo- } \\
\text { wieckiego. }\end{array}$ & & $\mathrm{x}$ \\
\hline & Pielgrzymi & Ustrzyki Dolne & $\begin{array}{l}\text { Osoby dorosłe z Podkarpacia zwiedzające } \\
\text { obiekty sakralne. }\end{array}$ & & $\mathrm{x}$ \\
\hline & Seniorzy & Ustrzyki Dolne & $\begin{array}{l}\text { Miłośnicy wędrówek i spacerów, korzystający } \\
\text { z walorów przyrodniczych gminy. }\end{array}$ & & $x$ \\
\hline \multirow[t]{2}{*}{$\begin{array}{l}\text { Segmenty } \\
\text { potencjalne }\end{array}$} & $\begin{array}{l}\text { Osoby zainteresowane } \\
\text { zielarstwem i paster- } \\
\text { stwem }\end{array}$ & Baligród & $\begin{array}{l}\text { Uczniowie szkół podstawowych i średnich, ro- } \\
\text { dziny z dziećmi. }\end{array}$ & $\mathrm{x}$ & \\
\hline & $\begin{array}{l}\text { Turyści kulturowi i piel- } \\
\text { grzymi }\end{array}$ & Baligród & Miłośnicy sztuki cerkiewnej i pielgrzymi. & $x$ & \\
\hline
\end{tabular}

Źródło: opracowanie własne na podstawie wyników badań.

Tabela 3. Główne wyzwania gmin w zakresie zarządzania SVF oraz proponowane rozwiązania problemów przez kluczowych interesariuszy

\begin{tabular}{|l|l|l|}
\hline \multicolumn{1}{|c|}{$\begin{array}{c}\text { Gmina i charakterystyka } \\
\text { ruchu turystycznego }\end{array}$} & \multicolumn{1}{|c|}{ Problemy/wyzwania } & \multicolumn{1}{c|}{$\begin{array}{c}\text { Zaproponowane rozwiązania } \\
\text { przez interesariuszy }\end{array}$} \\
\hline $\begin{array}{l}\text { Gmina Baligród } \\
\text { W gminie występuje przewaga } \\
\text { turystów jednodniowych przyjeż- } \\
\text { dżających głównie od maja do } \\
\text { września, średnie wydatki } \\
\text { 100-200 zł/osobę. Wszystkie SVFs } \\
\text { znajdują się w fazie wzrostu. }\end{array}$ & $\begin{array}{l}\text { Trudności związane z dostępnością komunika- } \\
\text { cyjną gminy. Obecnie mogą tam dojechać głów- } \\
\text { nie turyści zmotoryzowani, natomiast oferta } \\
\text { dla osób preferujących dojazd środkami komu- } \\
\text { nika-cji publicznej jest bardzo ograniczona. }\end{array}$ & $\begin{array}{l}\text { Stworzenie systemu zachęt w gminie dla osób } \\
\text { chcących zainwestować w przewóz osób komuni- } \\
\text { kacją zbiorową. }\end{array}$ \\
\cline { 2 - 3 } & $\begin{array}{l}\text { głabo rozwinięta baza gastronomiczna i nocle- } \\
\text { gowazaz atrakcje dla dzieci (place zabaw, } \\
\text { bo-iska, miejsca aktywnego spędzania czasu). }\end{array}$ & $\begin{array}{l}\text { Intensyfikacja współpracy władz gminy z lokalną } \\
\text { społecznością i przedsiębiorcami dla zwiększenia } \\
\text { oferty noclegowo-gastronomicznej (np. miejsc } \\
\text { kempingowych oraz atrakcji dla dzieci). Stworze- } \\
\text { nie systemu zachęty dla nowych inwestorów. }\end{array}$ \\
\hline
\end{tabular}


Tabela 3 (cd.)

\begin{tabular}{|c|c|c|}
\hline $\begin{array}{l}\text { Gmina i charakterystyka } \\
\text { ruchu turystycznego }\end{array}$ & Problemy/wyzwania & $\begin{array}{c}\text { Zaproponowane rozwiązania } \\
\text { przez interesariuszy }\end{array}$ \\
\hline & $\begin{array}{l}\text { Słabe oznakowanie atrakcji oraz oferty tu- } \\
\text { rystycznej gminy. }\end{array}$ & $\begin{array}{l}\text { Wprowadzenie zunifikowanego systemu ozna- } \\
\text { kowania atrakcji turystycznych oraz miejsc noc- } \\
\text { legowych i gastronomicznych celem zatrzyma- } \\
\text { nia turystów tranzytowych i zwiększenia ruchu } \\
\text { turystycznego w gminie. }\end{array}$ \\
\hline & Niewielka długość i liczba tras rowerowych. & $\begin{array}{l}\text { Wydłużenie tras rowerowych i połączenie ich } \\
\text { z trasami gminy Cisna jest, zdaniem interesariu- } \\
\text { szy, kluczowe dla przyciągnięcia rowerzystów. } \\
\text { W tym celu konieczne jest stworzenie wspólnego } \\
\text { projektu tras rowerowych i zacieśnienie współ- } \\
\text { pracy między gminami Baligród i Cisna. }\end{array}$ \\
\hline \multirow[t]{2}{*}{$\begin{array}{l}\text { Gmina Cisna } \\
\text { W tej gminie występuje przewaga } \\
\text { turystów (nocujących } 3 \text { doby } \\
\text { i więcej), przyjeżdżających głównie } \\
\text { od marca do października. } \\
\text { Wszystkie SVFs znajdują się } \\
\text { w fazie wzrostu. }\end{array}$} & $\begin{array}{l}\text { Brak schronisk (bazy noclegowej na trasach } \\
\text { górskich). Brak komunikacji lokalnej. Zbyt } \\
\text { mała liczba parkingów oraz ścieżek rowero- } \\
\text { wych. Słaba dostępność komunikacyjna miej- } \\
\text { scowości. }\end{array}$ & $\begin{array}{l}\text { Intensyfikacja działań i współpracy lokalnego sa- } \\
\text { morządu, przedsiębiorstw i stowarzyszeń w celu } \\
\text { budowy 2-3 nowych schronisk oraz opracowania } \\
\text { systemu zachęt dla prywatnych przewoźników } \\
\text { do stworzenia w sezonie oferty komunikacji zde- } \\
\text { cydowanie zwiększyłaby długość pobytu tury- } \\
\text { stów. W tym celu zaproponowano wzmocnienie } \\
\text { partnerstwa publiczno-prywatnego w obrębie } \\
\text { gminy. }\end{array}$ \\
\hline & $\begin{array}{l}\text { Zbyt mała oferta dla dzieci. Dotyczy to za- } \\
\text { równo infrastruktury, jak i programu anima- } \\
\text { cyjnego przygotowanego dla najmłodszych. }\end{array}$ & $\begin{array}{l}\text { Stworzenie programu animacji dla dzieci w okre- } \\
\text { sie letnim (zarówno atrakcji płatnych, jak i bezpłat- } \\
\text { nych) oraz poszerzenie infrastruktury. }\end{array}$ \\
\hline \multirow{3}{*}{$\begin{array}{l}\text { Gmina Olszanica } \\
\text { W skład SVFs w gminie wchodzą } \\
\text { zarówno turyści nocujący w ba- } \\
\text { zie, jak i przyjeżdżający jedno- } \\
\text { dniowi. Turyści wydają średnio } \\
\text { między } 350 \text { a } 400 \text { zł/osobę. } \\
\text { Wszystkie segmenty w fazie dy- } \\
\text { namicznego wzrostu, głównie od } \\
\text { kwietnia do listopada. }\end{array}$} & $\begin{array}{l}\text { Brak nowych inwestorów w branży tury- } \\
\text { stycznej. }\end{array}$ & $\begin{array}{l}\text { Konieczne jest stworzenie przez gminę systemu } \\
\text { zachęt dla nowych inwestorów. }\end{array}$ \\
\hline & $\begin{array}{l}\text { Brak oferty ekskluzywnej dla rodzin i tury- } \\
\text { stów dobrze sytuowanych, których coraz } \\
\text { więcej pojawia się w gminie Olszanica. }\end{array}$ & $\begin{array}{l}\text { Opracowanie nowej oferty produktowej, pozwala- } \\
\text { jącej na wydłużenie pobytów w gminie, np. przez } \\
\text { imprezy cykliczne, koncerty, dywersyfikację cen } \\
\text { i przemyślaną reklamę. }\end{array}$ \\
\hline & $\begin{array}{l}\text { Stworzenie dodatkowych atrakcji, by zatrzy- } \\
\text { mać turystę na dłużej. }\end{array}$ & $\begin{array}{l}\text { Wprowadzenie oznakowania wszystkich szlaków } \\
\text { turystycznych oraz zagospodarowanie wodospadu. } \\
\text { Intensyfikacja współpracy między lokalnymi } \\
\text { przewodnikami, właścicielami pensjonatów i sa- } \\
\text { morządem lokalnym. Nowa kampania reklamo- } \\
\text { wa w mediach społecznościowych, finansowana } \\
\text { ze środków publiczno-prywatnych. }\end{array}$ \\
\hline \multirow{5}{*}{$\begin{array}{l}\text { Gmina Lesko } \\
\text { W tej gminie występuje przewaga } \\
\text { turystów jednodniowych i tranzy- } \\
\text { towych. Turystami są głównie } \\
\text { wędkarze i szybownicy, nato- } \\
\text { miast przyjeżdżający jednodniowi } \\
\text { to grupy zorganizowane i narcia- } \\
\text { rze. Grupy szkolne w spadkowej } \\
\text { fazie cyklu życia, pozostałe SVFs } \\
\text { w fazie wzrostu i dojrzałości. Wy- } \\
\text { datki od } 40 \text { zł do kilkuset zł na } \\
\text { osobę na dzień pobytu. }\end{array}$} & $\begin{array}{l}\text { Segment narciarski znajduje się w początko- } \\
\text { wej fazie rozwoju. }\end{array}$ & $\begin{array}{l}\text { Rozbudowa infrastruktury narciarskiej dla przy- } \\
\text { ciągnięcia większej liczby narciarzy spoza gminy. }\end{array}$ \\
\hline & $\begin{array}{l}\text { Pokutuje stereotyp, że Lesko jest miastem } \\
\text { tranzytowym w Bieszczady i nad Solinę, } \\
\text { dlatego zbyt krótkie (najczęściej jedno- } \\
\text { dniowe) pobyty w gminie i w Lesku wycie- } \\
\text { czek zorganizowanych i grup szkolnych. }\end{array}$ & $\begin{array}{l}\text { Budowa parkingu dla autokarów w centrum miasta. } \\
\text { Stworzenie ciekawych atrakcji dla dzieci, moder- } \\
\text { nizacja infrastruktury, nowoczesne podejście do } \\
\text { grup zorganizowanych i lepsze zarządzanie ich } \\
\text { obsługą. Konieczne jest głębsza współpraca na } \\
\text { linii samorząd-lokalni przedsiębiorcy-przewod- } \\
\text { nicy miejscowi. }\end{array}$ \\
\hline & $\begin{array}{l}\text { Poza basenem mało jest ofert dla turystów } \\
\text { in-dywidualnych i grup, które mogłyby być } \\
\text { ofe-rowane w czasie niepogody. }\end{array}$ & \multirow{2}{*}{$\begin{array}{l}\text { Opracowanie sytemu ofert pozwalającego na łą- } \\
\text { czenie atrakcji turystycznych i usług dodatko- } \\
\text { wych (np. gastronomicznych), co pozwoliłoby cie- } \\
\text { kawie spędzać czas w gminie Lesko bez względu } \\
\text { na pogodę i porę roku. }\end{array}$} \\
\hline & $\begin{array}{l}\text { Słaba dostępność atrakcji oraz ich wypromo- } \\
\text { wanie, co skutkuje niedoinformowaniem tu- } \\
\text { rystów i pomijaniem atrakcji o unikalnych } \\
\text { walorach kulturowych i naturalnych } \\
\end{array}$ & \\
\hline & $\begin{array}{l}\text { Niesatysfakcjonująca obsługa turystów za- } \\
\text { granicznych w językach obcych, m.in. węd- } \\
\text { karzy i szybowników. }\end{array}$ & $\begin{array}{l}\text { Konieczne są szkolenia językowe dla personelu } \\
\text { bezpośrednio zaangażowanego w obsługę tego } \\
\text { SVF na obszarze gminy. Stworzenie ofert specjal- } \\
\text { nych dla międzynarodowych grup wędkarskich, } \\
\text { paralotniarzy i szybowników, przebywających } \\
\text { w gminie min. } 3 \text { dni i generujących duże przy- } \\
\text { chody, w celu zachęcenia ich do zobaczenia atrak- } \\
\text { cji, których podczas pobytu najczęściej w ogóle nie } \\
\text { zwiedzają. }\end{array}$ \\
\hline
\end{tabular}


Tabela 3 (cd.)

\begin{tabular}{|c|c|c|}
\hline $\begin{array}{l}\text { Gmina i charakterystyka } \\
\text { ruchu turystycznego }\end{array}$ & Problemy/wyzwania & $\begin{array}{c}\text { Zaproponowane rozwiązania } \\
\text { przez interesariuszy }\end{array}$ \\
\hline & $\begin{array}{l}\text { Spływy rzeczne cieszą coraz większym } \\
\text { zainteresowaniem grup, ale brak jest } \\
\text { przystani. Występuje także problem } \\
\text { z niestabilnym stanem wody w rzece San. }\end{array}$ & $\begin{array}{l}\text { Zbudowanie przystani, lepsze wypromowanie } \\
\text { atrakcji wodnych. Poprawienie poziomu bezpie- } \\
\text { czeństwa turystów korzystających ze spływów } \\
\text { rzecznych. }\end{array}$ \\
\hline $\begin{array}{l}\text { Gmina Solina } \\
\text { Spośród wszystkich sześciu gmin } \\
\text { przyciąga ona - ze względu na } \\
\text { malownicze jezioro - najwięcej } \\
\text { turystów. Są to podróżni nocują- } \\
\text { cych od } 3 \text { dni do tygodnia i dłu- } \\
\text { żej. Różnorodność segmentów } \\
\text { i długó́ć ich pobytów sprawia, } \\
\text { że ruch turystyczny jest znacznie } \\
\text { wydłużony w stosunku do in- } \\
\text { nych gmin (w Polańczyku z } \\
\text { uwagi na turystów sanatoryjnych } \\
\text { ruch trwa cały rok). Turyści nocu- } \\
\text { jący w bazie również wydają wię- } \\
\text { cej pieniędzy niż w innych gmi- } \\
\text { nach, tj. od } 100 \text { zł do kilkuset zł na } \\
\text { osobę za dzień pobytu. }\end{array}$ & $\begin{array}{l}\text { Za mało strzeżonych kąpielisk oraz tras } \\
\text { biegowych. Problemy dotyczące } \\
\text { bezpieczeństwa oraz braku atrakcji } \\
\text { w razie niepogody. }\end{array}$ & $\begin{array}{l}\text { Intensyfikacja partnerstwa publiczno-prywatnego } \\
\text { w celu: } \\
\text { - poprawy bezpieczeństwa kąpiących się oraz } \\
\text { żeglarzy, } \\
\text { - stworzenia większej liczby kąpielisk strzeżo- } \\
\text { nych oraz portów z możliwością przycumowa- } \\
\text { nia statków wycieczkowych i jachtów, } \\
\text { - lepszego zabezpieczenia tras pływackich } \\
\text { i biegowych, } \\
\text { - stworzenia nowych atrakcji niezależnych } \\
\text { od pogody. } \\
\text { Zwiększenie liczby przewodników lokalnych, } \\
\text { którzy zachęcą do wycieczek po okolicy. }\end{array}$ \\
\hline \multirow{3}{*}{$\begin{array}{l}\text { Gmina Ustrzyki Dolne } \\
\text { W tej gminie przeważają turyści } \\
\text { nocujący w bazie i grupy, } \\
\text { co rokuje szansę na rozwój } \\
\text { ruchu turystycznego. }\end{array}$} & $\begin{array}{l}\text { Zatrzymanie turysty na więcej niż } 3 \text { doby } \\
\text { zarówno latem, jak i zimą. }\end{array}$ & $\begin{array}{l}\text { Rozbudowa wyciągów, powiększenie oferty } \\
\text { wydarzeń o charakterze kulturowym - festiwale } \\
\text { dotyczące Ustrzyk Dolnych. }\end{array}$ \\
\hline & $\begin{array}{l}\text { Poszerzenie atrakcji, SPA, ścieżek turystycz- } \\
\text { nych i tras rowerowych. }\end{array}$ & $\begin{array}{l}\text { Rozbudowa infrastruktury i utworzenie przejścia } \\
\text { granicznego pozwalającego na zwiększanie ruchu } \\
\text { turystyczny w gminie. } \\
\text { Rozbudowa tras rowerowych i pieszych. } \\
\text { Stworzenie programu kilku dużych imprez } \\
\text { o znaczeniu ogólnopolskim. } \\
\text { Konieczna jest intensyfikacja współpracy między } \\
\text { samorządem a lokalnymi przedsiębiorcami. }\end{array}$ \\
\hline & $\begin{array}{l}\text { Brak oferty powodującej ożywienie ruchu } \\
\text { turystycznego poza sezonem. }\end{array}$ & $\begin{array}{l}\text { Przyciągnięcie do gminy seniorów i osób niemają- } \\
\text { cych dzieci w wieku szkolnym oraz stworzenie dla } \\
\text { nich specjalnych pakietów przed-i posezonowych. }\end{array}$ \\
\hline
\end{tabular}

Źródło: opracowanie własne na podstawie wyników badań.

Pozytywny przykład współpracy samorządu z lokalnymi przedsiębiorcami mogą stanowić niedawno utworzone atrakcje turystyczne $\mathrm{w}$ gminie Olszanica (np.: drezyny rowerowe, Ekomuzeum, Bieszczadzka Szkoła Rzemiosła i browar Ursa Maior $\left.{ }^{6}\right)$. Ze względu na bliskość Bieszczadzkiego Parku Narodowego gminy Cisna i Ustrzyki Dolne również starają się przyciągnąć turystów i przekonać ich do dłuższych przyjazdów turystycznych, tworząc ofertę pobytową od trzech do siedmiu dni. Natomiast na podstawie analizy wyników map można stwierdzić, że gminy Lesko i Baligród zdecydowanie w najmniejszym stopniu wykorzystują swój potencjał turystyczny. Pomimo tranzy towego położenia, bezpośrednio na trasie prowadzącej do gminy Solina, oferta tych dwóch gmin jest najmniej atrakcyjna dla turystów z kluczowych SVFs. Najważniejsze atrakcje nie są tu dobrze oznakowane ani wypromowane, co powoduje, że turyści zatrzymują się $w$ tych miejscach tylko po to, by skorzystać z oferty gastronomicznej lub zrobić zakupy.
W związku z tym, szczególnie w tych dwóch gminach, pojawia się konieczność wzmocnienia współpracy pomiędzy samorządem a lokalnymi przedsiębiorcami.

Podsumowując, należy stwierdzić, że wdrożona metoda pozwoliła interesariuszom na dostrzeżenie konieczności zacieśniania lokalnej i międzygminnej współpracy. Dyskusje w trakcie spotkań roboczych zainspirowały ich także do myślenia wykraczającego poza granice gmin, aby zaplanować wspólne działania w celu utrzymania istniejących strategicznych przepływów i rozwinięcia nowych SVFs.

\section{PODSUMOWANIE}

Wdrożona w wybranych bieszczadzkich gminach metoda The St. Gallen Model for Destination Management, pozwoliła zidentyfikować kluczowe segmenty turystów 
(SVFs) we wszystkich sześciu gminach biorących udział w implementacji modelu, co pomogło znaleźć odpowiedź na pierwsze pytanie badawcze. Ponadto dzięki pracy z mapami interesariusze określili, jakie główne elementy podaży są aktywowane przez kluczowe segmenty turystów, umożliwiając tym samym identyfikację tych atrakcji i miejsc o szczególnych walorach turystycznych, których siła przyciągania pozostaje wciąż niewykorzystana (odpowiedź na drugie pytanie badawcze). Jak się okazuje, większość miejsc i atrakcji, które są najczęściej pomijane przez turystów, znajduje się w gminach ościennych przylegających do gminy Solina. Dotyczy to w szczególności gmin Lesko i Baligród, odgrywających rolę miejsc tranzytowych, w których turyści albo w ogóle się nie zatrzymują, albo robią to na krótki czas (np. w celu zrobienia zakupów).

Wypełnione legendy map umożliwiły także ujawnienie głównych problemów poszczególnych gmin w zakresie zarządzania kluczowymi przepływami turystów (SVFs) oraz podziału kompetencji i zasobów, co nawiązuje do trzeciego pytania badawczego. W gminie Baligród i Olszanica zwrócono uwagę m.in. na brak zainteresowania inwestorów tworzeniem nowych atrakcji i inwestowaniem w rozbudowę bazy turystycznej. Brak środków finansowych na budowę infrastruktury turystycznej i okołoturystycznej, nie wydaje się jednak głównym problemem gmin, które wzięły udział w implementacji modelu SGDM.

Według interesariuszy dominującym wyzwaniem występującym we wszystkich gminach jest przede wszystkim niewystraczająca współpraca na linii samorząd lokalny-przedsiębiorcy-przewodnicy górscy oraz trudności w podziale kompetencji i koordynacji działań między poszczególnymi podmiotami. Grupa przewodników bieszczadzkich obecna na spotkaniach zwracała także uwagę na brak wsparcia dla ich usług zarówno ze strony samorządów lokalnych, jak i przedsiębiorców turystycznych, w szczególności zaś ze strony biur podróży turystyki przyjazdowej oraz punktów informacji turystycznej. Niezbyt intensywna jest także - jak się wydaje - współpraca międzygminna, niezwykle istotna dla stworzenia wspólnej lokalnej oferty turystycznej, np. dla rowerzystów (trasy rowerowe łączące gminy Baligród i Cisna) czy narciarzy (zintegrowana oferta na terenie gmin Lesko i Ustrzyki Dolne), jak również dla turystów zagranicznych (obsługa w językach obcych). W wielu gminach istnieje także problem oznakowania turystycznego atrakcji i szlaków, które powinno zostać zunifikowane na obszarze wszystkich sześciu gmin.

Poza całoroczną ofertą sanatoryjną rozwiniętą w gminie Solina większość objętych badaniem gmin nie posiada oferty pobytowej, która przyciągałyby turystów przez cały rok. Koncentracja ruchu turystycznego następuje tam głównie od maja do listopada, co - zwłaszcza w sezonie letnim - powoduje ogromne utrudnienia komunikacyjne na drogach dojazdowych do poszczególnych gmin oraz długie kolejki do dostępnych w nich atrakcji i punktów gastronomicznych. Na te problemy nakłada się brak oferty zintegrowanego transportu publicznego.

Po przeprowadzonych spotkaniach interesariusze przyznali w anonimowej ankiecie, że zastosowany model SGDM pozytywnie wpłynął na zmianę postrzegania przez nich turystyki jako systemu powiązań między popytem a podażą. Dzięki wdrożonej metodzie wzrosło także ich poczucie konieczności współdziałania, poprzez uświadomienie im, że długofalowy rozwój turystyki jest wspólną sprawą wszystkich (czwarte pytanie badawcze). Jak się wydaje, jest to największa uniwersalna zaleta wdrożonej metody, co znajduje odzwierciedlenie również w studiach przypadków innych destynacji, opisanych w cytowanej wcześniej książce pt. The St. Gallen model for destination management (SGDM) (Beritelli, Reinhold, Leasser, Bieger, 2015).

Ujawnione problemy i wyzwania, z którymi zmagają się obecnie bieszczadzkie gminy w zakresie zarządzania SVFs, wymagają zrobienia kolejnego kroku, czyli zaplanowania i wdrożenia - zarówno na szczeblu lokalnym, jak i międzygminnym - rozwiązań, które wypracowano podczas spotkań roboczych. Obecnie są podejmowane działania mające na celu pozyskanie środków na kontynuowanie implementacji metody SGDM w wymienionych gminach.

Uniwersalny charakter tego modelu daje również możliwość zastosowania The St. Gallen Model for Destination Management $\mathrm{w}$ innych miejscach recepcji turystycznej w Polsce, szczególnie tam, gdzie występują duże dysproporcje $\mathrm{w}$ ruchu turystycznym między poszczególnymi destynacjami.

\section{PRZYPISY}

1 Wdrożenie metody w Polsce było możliwe dzięki wsparciu finansowemu otrzymanemu od Ministerstwa Sportu i Turystyki i odbyło się w ramach projektu „Innowacyjne narzędzia wsparcia dla terytorialnej marki turystycznej Bieszczadów”.

${ }^{2} \mathrm{~W}$ projekcie nie wzięli udziału reprezentanci gminy Lutowiska - największej graniczącej z gminą Solina. Wyniknęło to z kilku powodów. Przede wszystkim w związku z małą gęstością zaludnienia, a także ze względu na fakt, że większość atrakcyjnych turystycznie obszarów gminy jest objęta ścisłą ochroną w ramach parku narodowego, trudno było zidentyfikować tutaj kluczowych interesariuszy prywatnych, mających wpływ na kształtowanie ruchu turystycznego. Natomiast zarówno przedstawiciele parku, jak i władze gminy zdają się przedkładać ochronę dziedzictwa naturalnego nad rozwój turystyki na tym obszarze, w związku z czym w tej edycji projektu nie wzięli oni udziału w implementacji metody SGDM.

3 Selekcji i zaproszenia interesariuszy na spotkania dokonali pracownicy Stworzenia Pro Carpathia - lokalnie działającego podmiotu, od lat wspierającego rozwój turystki na Podkarpaciu.

${ }^{4} \mathrm{~W}$ realizacji metody w Bieszczadach wzięli udział jej współautor, prof. Pietro Beritelli z Uniwersytetu St. Gallen, oraz autorka niniejszego artykułu. 
${ }^{5}$ Kwestionariusz składał się z czterech pytań: 1. Jak postrzegam rolę mojej firmy/instytucji/organizacji w zarządzaniu kluczowymi SVF? Z jakimi partnerami i na jaką skalę moja firma/ organizacja najchętniej współpracuje na rzecz rozwoju kluczowych segmentów? 3. Jaką część budżetu moja firma/instytucja inwestuje w działania marketingowe i innowacje produktowe? 4 . Co dał mi udział w spotkaniach roboczych z wykorzystaniem metody SGDM?

${ }^{6}$ Pomimo wcześniejszego braku jakiejkolwiek oferty turystycznej w gminie Olszanica, dzięki poczynionym inwestycjom ruch turystyczny w tej destynacji wynosi obecnie ok. 100 tys. osób rocznie (źródło: dane uzyskane od właścicieli wymienionych atrakcji).

\section{BIBLIOGRAFIA}

Baggio, R., Scott, N., Cooper, C. (2010). Improving tourism destination governance: a complexity science approach. Tourism Review, 65 (4), 51-60.

Baker, M.J., Cameron, E. (2008). Critical success factors in destination marketing. Tourism and Hospitality Research, 8, 79-97.

Barnes, S.J., Mattsson, J., Sørensen, F. (2014). Destination brand experience and visitor behavior: Testing a scale in the tourism context. Annals of Tourism Research, 48, 121-139.

Benčič, M. (2006). Recognizing the importance of tourism's strategy at the local community. Organization - Journal of Management. Information Systems and Human Resources, 39 (2), 141-145.

Beritelli, P. (2011a). Cooperation among prominent actors in a tourist destination. Annals of Tourism Research, 38 (2), 607-629.

Beritelli, P. (2011b). Tourist destination governance through local elites - looking beyond the stakeholder level. Cumulative postdoctoral thesis. University of St. Gallen.

Beritelli, P., Bieger, T., Laesser, C. (2007). Destination governance: Using corporate governance theories as a foundation for effective destination management. Journal of Travel Research, 46 (1), 96-107.

Beritelli, P., Laesser, C. (2011). Power dimensions and influence reputation in tourist destinations: Empirical evidence from a network of actors and stakeholders. Tourism Management, 32 (6), 1299-1309.

Beritelli, P., Reinhold, S., Leasser, Ch., Bieger, T. (2015). The St. Gallen model for Destination Management (SGDM). St. Gallen: St. Gallen University.

Bieger, T. (1998). Reengineering Destination Marketing Organisations: the case of Switzerland. Tourism Review, 53 (3), 4-17.

Bieger, T., Freyer, W. (ed.) (2005). Management von Destinationen. München: Oldenbourg.

Bieger, T., Beritelli, P., Leasser C. (2009). Size matters! Increasing DMO effectiveness and extending tourism destination boundaries. Tourism Review, 57 (3), 309-327.

Borzyszkowski, J. (2013). Współczesne wyzwania Destination Management Organisations (DMO). Research Works of University of Economics in Wroctaw, 303, 49-57.

Bornhorst, T., Ritchie, J.R.B., Sheehan, L. (2010). Determinants of tourism success for DMOs \& destinations: An empirical examination of stakeholders' perspectives. Tourism Management, 31 (5), 572-589.

Buhalis, D. (2000). Marketing the competitive destination of the future. Tourism Management, 21, 97-116.

Byrd, E.T. (2007). Stakeholders in sustainable tourism development and their roles: applying stakeholder theory to sustainable tourism development. Tourism Review, 62 (2), 6-13.

Crouch, G.I. (2011). Destination competitiveness: An analysis of determinant attributes. Journal of Travel Research, 50 (1), 27-45.
Czernek, K. (2012). Region turystyczny w ujęciu systemowym a potrzeba współpracy na rzecz rozwoju turystyki $\mathrm{w}$ regionie. Turystyka i Hotelarstwo, 18, 9-26.

Debarbieux, B., Oiry Varacca, M., Rudaz, G., Maselli, D., Kohler, T., Jurek, M. (2014). Tourism in mountain regions: hopes, fears and realities. Geneva: UNIGE, CDE, SDC.

Dwyer, L., Edwards, D., Mistilis, N., Roman, C., Scott, N. (2009). Destination and enterprise management for a tourism future. Tourism Management, 30 (1), 63-74.

Elbe, J., Hallén, L., Axelsson, B. (2009). The destination - management organization and the integrative destination - marketing process. International Journal of Tourism Research, 11 (3), 283-296.

Fedyk, W., Meyer, B., Potocki, J. (2017). Nowa koncepcja zarządzania regionami turystycznymi. Studia Oeconomica Posnaniensia, $5(4), 50-81$.

Fine, C.H. (2000). Clockspeed-based strategies for supply chain design. Production and Operations Management, 9 (3), 213-221.

Galaskiewicz, J. (1995). The making of organizational reputations. University of Minnesota, Mimeo. (niepublikowany).

Gretzel, U., Fesenmaier, D.R., Formica, S., O'Leary, J.T. (2006) Searching for the future: Challenges faced by Destination Marketing Organizations. Journal of Travel Research, 45 (2), 116-26.

Gunn, C. (1972). Vacationspace: designing tourist regions. Austin: Bureau of Business Research, University of Texas.

Gursoy, D., Saayman, M., Sotiriadis, M. (red.) (2015). Collaboration in tourism businesses and destinations: a handbook. Bingley: Emerald Group Publishing.

Haugland, S.A., Ness, H., Grønseth, B.O., Aarstad, J. (2011). Development of tourism destinations: an integrated multi-level perspective. Annals of Tourism Research, 38 (1), 268-290.

Keller, P. (2000). Destination marketing: strategic area of inquiry. W: M. Manete, M. Careto (red.), From destination to destination marketing and management. Designing and repositioning tourism products (s. 29-44). Venice: Ca'Foscarina University.

Kim, H., Richardson, S.L. (2003). Motion picture impacts on destination images. Annals of Tourism Research, 30 (1), 216-237.

Klimek, K. (2013). Destination Management Organizations and their shift to sustainable tourism development. European Journal of Tourism and Hospitality Research, 4 (2), 27-47.

Klimek, K. (2014). State tourism policies in Switzerland and selected good practices for polish tourism. Folia Turistica, 33, 35-61.

Klimek, K., Doctor, M. (2018). Are Alpine destination management organizations (DMOs) appropriate entities for the commercialization of summer tourism products? Journal of Destination Marketing \& Management, 10, 181-190.

Laesser, Ch., Beritelli, P. (2013). St. Gallen consensus on destination management. Journal of Destination Marketing $\mathcal{E}$ Management, 2, 46-49.

Lai, P.H., Hsu, Y.C., Wearing, S. (2016). A social representation approach to facilitating adaptive co-management in mountain destinations managed for conservation and recreation. Journal of Sustainable Tourism, 24 (2), 227-244.

Leiper, N. (1990). Tourist attraction systems. Annals of Tourism Research, 17 (3), 367-384.

Myga-Piątek, U., Jankowski, G. (2009). Wpływ turystyki na środowisko przyrodnicze i krajobraz kulturowy - analiza wybranych przykładów obszarów górskich. Problemy Ekologii Krajobrazu, 25, 25-48.

Nestorosk, I. (2012). Identifying tourism potentials in Republic of Macedonia through regional approach. Procedia-Social and Behavioral Sciences, 44, 95-103.

Padurean, L. (2010). Destinations dynamic: a management and governance perspective. Praca doktorska. Lugano: Univesità della Svizzera Italiana.

Pearce, D.G. (1995). Tourism today: a geographical analysis. Wyd. 2. Harlow: Longman Scientific \& Technical. 
Pearce, D.G. (2014). Toward an integrative conceptual framework of destinations. Journal of Travel Research, 53 (2), 141-153

Pechlaner, H., Tschurtschenthaler, P. (2003). Tourism policy, tourism organizations and change management in Alpine regions and destinations: a European perspective. Current Issues in Tourism, 6, 508-539.

Presenza, A., Sheehan, L., Ritchie, J.B. (2005). Towards a model of the roles and activities of destination management organizations. Journal of Hospitality, Tourism and Leisure Science, 3 (1), 1-16.

Richards, G. (2002). Tourism attraction systems: Exploring cultural behavior. Annals of Tourism Research, 29 (4), 1048-1064.

Ritchie, J.R.B., Hudson, S. (2009). Understanding and meeting the challenges of consumer-tourist experience research. International Journal of Tourism Research, 11, 111-126.

Sheehan, L.R., Ritchie, J.R. (2005). Destination stakeholders exploring identity and salience. Annals of Tourism Research, 32 (3) 711-734.

Świgost, A. (2017). The transformation of the natural environment of the Polish and Ukrainian Bieszczady mountains due to tourism and other forms of human pressure. Current Issues of Tourism Research, 5 (2), 27-35.
Szulc-Dąbrowiecka, E., Żuławska, U. (2015). Zarządzanie regionem turystycznym: przykład regionu Bieszczad w latach 1952-2014. Przedsiębiorczość i Zarządzanie, 14 (4), 99-112.

UNWTO (2007). A practical guide to tourism destination management. Madrid: World Tourism Organization.

US (2018). Turystyka w województwie podkarpackim w 2017 r. Rzeszów: Urząd Statystyczny w Rzeszowie.

Vengesayi, S. (2003). A conceptual model of tourism destination competitiveness and attractiveness. W: R. Kennedy, Proceedings of the 2003 Conference ANZMAC (s. 637-647). Adelaide: ANZMAC.

Wolski, J. (2007). Przekształcenia krajobrazu wiejskiego Bieszczadów Wysokich w ciagu ostatnich 150 lat (Transformations of the High Bieszczady Mountains rural landscape during the last 150 years). Warszawa: IGiPZ PAN.

Artykuł wpłynął: 8 czerwca 2019 r. Zaakceptowano do druku: 29 sierpnia $2019 \mathrm{r}$. 
